http://nv.nltu.edu.ua

https://doi.org/10.15421/40280506

Article received 11.05.2018 $p$.

Article accepted 31.05.2018 p.

УДК $630 *[116+221]$

$@ \bowtie$ Correspondence author

Yu. I. Pankivskyi

yuriypankivskyi@ukr.net

О. Є. Ошуркевич-Панківська, Ю. І. Панківський

Національний лісотехнічний університет Украйни, м. Львів, Украӥна

\title{
ВПЛИВ ЛІСУ НА НАГРОМАДЖЕННЯ І ТАНЕННЯ СНІГУ В ГОРАХ
}

На основі даних про витрати води, товщину снігового покриву і запаси води в снігу за період з 1981 по 1994 рр. для одинадцяти водозборів річок північного мегасхилу Українських Карпат (басейн річки Дністер) побудовано суміщені гідрографи стоку води і запасів води в снігу. На отриманих графіках виділено зимові паводки і весняні водопілля, для кожного $з$ яких визначено: тривалість, запас води в снігу на початок сніготанення, об'єм поверхневого і грунтового стоку. На основі результатів розрахунків та морфометричних характеристик водозборів, а саме: стрімкості схилів, висоти н.р.м., лісистості, проаналізовано вплив лісових насаджень на нагромадження снігу, тривалість та об'єми поверхневого стоку зимових паводків та весняних водопіль. Встановлено, що, порівняно з метеорологічними умовами і рельєфом місцевості, лісистість має менший вплив на формування снігового покриву, проте максимальні товщини снігового покриву простежено за лісистості водозбору в діапазоні 40-60\%; максимальний прояв стокорегулювальних можливостей лісу під час формування зимових паводків спостережено за снігозапасів понад 41 мм і проявляється у збільшенні тривалості паводків на 5-17 днів; максимальний прояв стокорегулювальних можливостей лісу під час весняних водопіль спостережено за снігозапасів понад 61 мм і проявляється у зменшенні об'єму поверхневого стоку водопілля у 1,1-1,3 раза.

Ключові слова: весняні водопілля; зимові паводки; запаси води в снігу; об'єм поверхневого стоку паводка; об'єм поверхневого стоку водопілля; тривалість паводка; тривалість водопілля.

Вступ. Формування стоку під час зимового та весняного сніготанення є наслідком таких взаємопов'язаних процесів, як: танення снігу, регулювання швидкості руху талих вод сніговим покривом, втрати стоку на інфільтрацію у грунт. Усі ці процеси, головно, залежать від особливостей рельєфу (Chubatyi, 1968), об'єму і швидкості стоку (Kulchitckii-Zhigailo, 2008; Molchanov, 1970), однак певна роль у формуванні весняних водопіль та зимових паводків належить рослинному вкриттю. Внаслідок затінення грунту кронами дерев процес сніготанення у лісі триває довше, ніж на відкритій місцевості, що сприяє зменшенню максимальних витрат зимових паводків та весняних водопіль (Kulchitckii-Zhigailo, \& Oshurkevich, 2007). Дослідження (KulchitckiiZhigailo \& Oshurkevich, 2007; Kulchitckii-Zhigailo, 2008; Subbotin, 1986) показали, що поєднання на річковому водозборі заліснених та незаліснених ділянок зумовлює найбільш тривалий період сніготанення і найменший максимум водопілля, тобто сприятливі умови для формування весняного стоку. На незалісненому водозборі сніготанення відбувається одночасно по всій території і закінчується швидше на 10-14 (Molchanov, 1970) і навіть на 15-30 (Dubakh, 1951) днів, порівняно з повністю залісненим водозбором. 3 огляду на це прийнято вважати, що лісові насадження під час зимового та весняного сніготанення зменшують частку поверхневої складової в загальному об'ємі стоку з водозборів (Chubatyi, 1968).
Проте, незважаючи на понад столітню історію лісівничо-гідрологічних досліджень, питання про стокорегулювальний вплив лісів, особливо в гірських умовах, залишається дискусійним.

Мета роботи - провести кількісну оцінку впливу лісу на процеси нагромадження і танення снігу на водозборах річок Українських Карпат.

Об'єкти та методика дослідження. Об'єктами досліджень були водозбори річок північного мегасхилу Українських Карпат (басейн р. Дністер). 3 морфометричних характеристик досліджених водозборів (табл. 1) видно, що на лісистих водозборах (р. Рибник с. Майдан; р. Рожанка - с. Рожанка; р. Орява - х. Святослав; р. Сукіль - с. Тисів) переважають листяні деревостани, на менш заліснених водозборах із пологими схилами - хвойні (р. Дністер - с. Стрілки; р. Яблунька м. Турка; р. Головчанка - с. Тухля).

На основі даних про витрати води, товщину снігового покриву і запаси води в снігу для кожного водозбору побудовано суміщені гідрографи стоку води і запасів води в снігу. На цих графіках виділено зимові паводки і весняні водопілля, потім для кожного з них визначено: тривалість, запас води в снігу до початку сніготанення, об̆'єм поверхневого і грунтового стоку. Загалом матеріали гідрометричних спостережень охоплювали період 3 1981 по 1994 pp.

Інформація про авторів:

Ошуркевич-Панківська Оксана Євгенівна, канд. с.-г. наук, ст. викладач, кафедра екології. Email: oxosh@ukr.net

Панківський Юрій Іванович, канд. ф.-м. наук, доцент, кафедра екологіï. Email: yuriypankivskyi@ukr.net

Цитування за ДСТУ: Ошуркевич-Панківська О. Є., Панківський Ю. І. Вплив лісу на нагромадження і танення снігу в горах. Науковий вісник НЛТУ України. 2018, т. 28, № 5. С. 31-34.

Citation APA: Oshurkevych-Pankivska, O. Ye., \& Pankivskyi, Yu. I. (2018). Influence of forest on snow accumulation and melting in the mountains. Scientific Bulletin of UNFU, 28(5), 31-34. https://doi.org/10.15421/40280506 
Табл. 1. Морфометричні характеристики досліджених водозборів

\begin{tabular}{|c|l|c|c|c|c|c|c|c|}
\hline $\begin{array}{c}\text { № } \\
\text { 3/п }\end{array}$ & \multicolumn{1}{|c|}{ Назва річки - пост } & $\begin{array}{c}\text { Середньозва- } \\
\text { жений ухил } \\
\text { річки, \%о }\end{array}$ & $\begin{array}{c}\text { Площа во- } \\
\text { дозбору, } \\
\text { км }\end{array}$ & $\begin{array}{c}\text { Середня ви- } \\
\text { сота водозбо- } \\
\text { ру, м }\end{array}$ & $\begin{array}{c}\text { Середній } \\
\text { ухил во- } \\
\text { дозбору, \%o }\end{array}$ & $\begin{array}{c}\text { Лісис- } \\
\text { тість, \% } \%\end{array}$ & $\begin{array}{c}\text { Частка } \\
\text { хвойних } \\
\text { порід*, } \%\end{array}$ & $\begin{array}{c}\text { Частка } \\
\text { листяних } \\
\text { порід*, \% }\end{array}$ \\
\hline 1 & р. Дністер - с. Стрілки & 5,9 & 384 & 620 & 180 & 40 & 37,8 & 2,2 \\
\hline 2 & р. Стрий - с. Матків & 7,2 & 106 & 860 & 161 & 56 & 37,7 & 18,3 \\
\hline 3 & р. Яблунька - м. Турка & 11,3 & 136 & 722 & 214 & 30 & 29,6 & 0,4 \\
\hline 4 & р. Рибник - с. Майдан & 19,1 & 138 & 830 & 326 & 93 & 44,5 & 48,4 \\
\hline 5 & р. Опір - м. Сколе & 6,3 & 733 & 820 & 294 & 50 & 41,3 & 8,7 \\
\hline 6 & р. Славськая - смт Славське & 15,9 & 76,3 & 860 & 260 & 53 & 46,9 & 6,1 \\
\hline 7 & р. Рожанка - с. Рожанка & 18,7 & 88,6 & 880 & 289 & 63 & 54,3 & 8,7 \\
\hline 8 & р. Головчанка - с. Тухля & 10,9 & 130 & 810 & 196 & 41 & 35,5 & 5,5 \\
\hline 9 & р. Орява - -. Святослав & 16,0 & 204 & 830 & 273 & 77 & 56,1 & 20,9 \\
\hline 10 & р. Лужанка - с. Гошів & 18,3 & 146 & 660 & 230 & 55 & 20,0 & 35,0 \\
\hline 11 & р. Сукіль - с. Тисів & 16,8 & 138 & 770 & 297 & 80 & 29,8 & 50,2 \\
\hline
\end{tabular}

Примітка: * Kulchitckii-Zhigailo, \& Oshurkevich, 2007

Результати дослідження та їх обговорення. Характер накопичення снігового покриву на всіх досліджених водозборах був загалом подібним (табл. 2). Формування снігового покриву починається у листопаді - грудні, а максимальна його товщина характерна для лютого. Товщина снігового покриву залежить від метеорологічних умов. Середнє значення товщини снігу за період сніготанення змінюється у межах від 7,52 до 20,74 см. У роки зі суворими та сніжними зимами на початок весни запаси води в снігу досягали $10 \mathrm{~cm}$, а інколи й перевищували це значення. Навпаки, у теплі з частими відлигами, зими сніговий покрив був нестійким і більша його частина живила річки під час потеплінь взимку, спричиняючи зимові паводки.
На початку весни (у березні) товщина снігу переважно зменшується внаслідок тимчасових короткочасних або ж довготривалих потеплінь.

Найбільше снігу нагромаджується на водозборі p. Стрий до с. Матків, що розміщений найвище 3 усіх досліджуваних водозборів (860 м н.р.м.), має один 3 найменших ухилів схилів (7,2 \%о) та понад 50 \% лісовкритої площі. Загалом максимальні товщини снігу формуються на високогірних річкових басейнах, де випадає більше опадів, ніж на пониззі. Очевидно, що значний ухил місцевості сприятиме швидкому сходженню снігу, хоч чіткої залежності на досліджуваних водозборах не простежуємо, незважаючи на максимальну зафіксовану товщину снігового вкриття за мінімального ухилу на водозборі р. Стрий - с. Матків.

Табл. 2. Середньомісячна товщина снігу за багатолітній період

\begin{tabular}{|c|c|c|c|c|c|c|c|c|}
\hline \multirow{2}{*}{$\begin{array}{c}\text { № } \\
\text { 3/ח }\end{array}$} & \multirow{2}{*}{ Назва річки - пост } & \multirow{2}{*}{ Лісистість, \% } & \multicolumn{6}{|c|}{ Товщина снігу, см } \\
\hline & & & листопад & грудень & січень & лютий & березень & середня за зиму \\
\hline 1 & р. Яблунька - м. Турка & 30 & 8,8 & 10,1 & 10,5 & 18,3 & $\overline{5,4}$ & 10,62 \\
\hline 2 & р. Славська - смт. Славське & 53 & 9,9 & 13,22 & 21 & 25,6 & 13,7 & 16,68 \\
\hline 3 & р. Дністер - с. Стрілки & 40 & 5,6 & 12,2 & 9,9 & 13,7 & 9,9 & 10,26 \\
\hline 4 & р. Рибник - с. Майдан & 93 & 5,4 & 14,7 & 11,1 & 17,6 & 14,5 & 12,66 \\
\hline 5 & р. Опір - м. Сколе & 50 & 8,0 & 10,3 & 7,3 & 11,6 & 9,2 & 9,28 \\
\hline 6 & р. Орява - х. Святослав & 77 & 9,7 & 15,3 & 17,1 & 17,9 & 16,6 & 15,32 \\
\hline 7 & p. Стрий - с. Матків & 56 & 14,3 & 17,5 & 22,8 & 27,4 & 21,7 & 20,74 \\
\hline 8 & р. Головчанка - с. Тухля & 41 & 8,1 & 15,6 & 19,1 & 21,3 & 16,8 & 16,18 \\
\hline 9 & р. Сукіль - с. Тисів & 80 & 4,1 & 6,4 & 5,6 & 10,4 & 11,1 & 7,52 \\
\hline 10 & р. Лужанка - с. Гошів & 55 & 6,3 & 7,3 & 8,1 & 9,9 & 13,7 & 9,06 \\
\hline 11 & р. Рожанка - с. Рожанка & 63 & 6,5 & 15,5 & 17,8 & 23,9 & 18,7 & 16,48 \\
\hline
\end{tabular}

3 огляду на те, що морфометричні характеристики досліджуваних водозборів сильно варіюють (див. табл. 1), чіткої тенденції впливу лісистості на нагромадження снігу не встановлено, але треба зауважити, що максимальні товщини снігового покриву простежують за лісистості в діапазоні 40-60 \% незалежно від співвідношення хвойних і листяних порід у лісових насадженнях.

Зі встановленого тренду зміни тривалості зимових паводків від залісненості водозбору (рис. 1) видно, що найвідчутніше на тривалість паводка впливає величина запасів води у снігу на початок сніготанення. Так за найбільших запасів снігу (80-100 мм) тривалість його може сягати 35 днів. I навпаки, коли снігозапаси незначні (10-12 мм), вона рідко перевищує 10 днів.

Ліс зумовлює збільшення тривалості зимових паводків внаслідок зменшення інтенсивності сніготанення, найвиразніше це проявляється за значних запасів води у снігу (понад 40 мм) на початок паводка. У цьому разі збільшення лісистості водозборів від $30 \%$ до $93 \%$ зумовлює підвищення тривалості зимових паводків на 517 днів. Вода, що утворюється під час танення, повіль- но і поступово надходить у русло, не спричиняючи різкого підняття рівнів. Коли ж на початок сніготанення, переважно у теплі з частими відлигами зими, запаси води у снігу незначні (менше 40 мм), вплив лісистості на тривалість паводка $\epsilon$ мінімальним. Очевидно, це пов'язано з адвективним типом потепління, коли теплі маси повітря надходять під намет лісу, спричиняючи інтенсивне сніготанення.

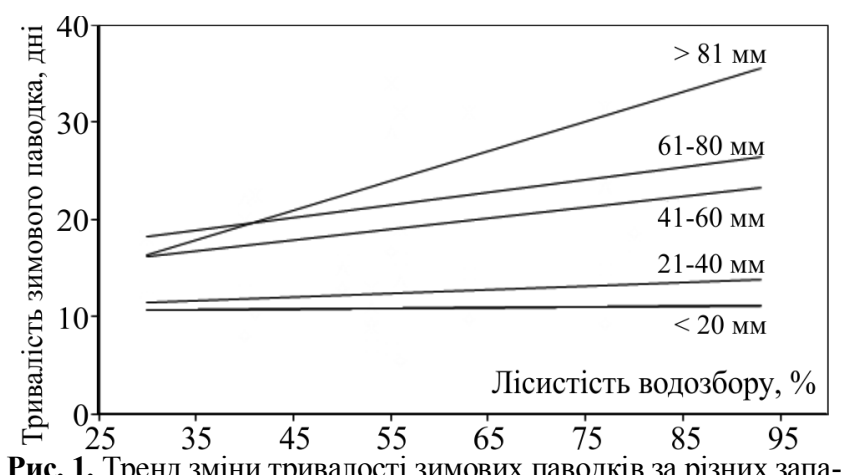

Рис. 1. Тренд зміни тривалості зимових паводків за різних запасів води в снігу на початок сніготанення 
Під час проходження паводків особливу небезпеку становить, так званий, поверхневий стік, який зумовлює різке підняття рівня води в руслі. Взимку, коли грунт ще замерзлий і не може поглинати воду, частка цього стоку є переважаючою. На рис. 2 зображено залежність об'єму поверхневого стоку зимових паводків від загальної лісистості водозбору за різних запасів води у снігу на початок сніготанення.

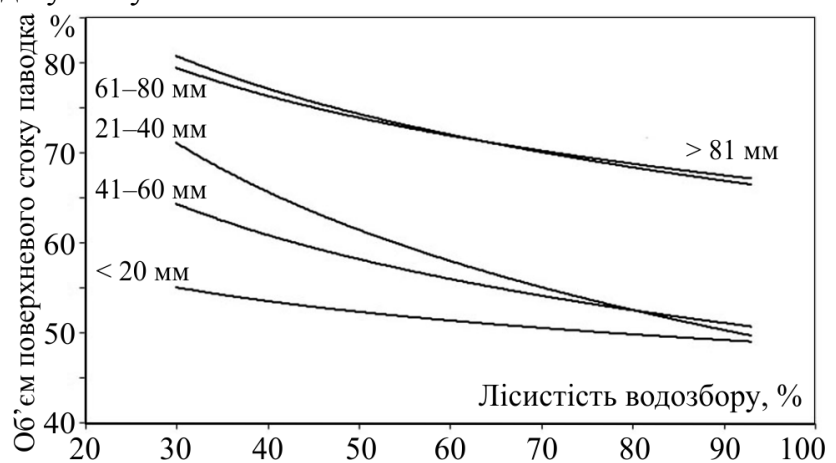

Рис. 2. Тренд зміни об'єму поверхневого стоку паводка за різних запасів води в снігу на початок сніготанення

Найбільші запаси води у снігу зумовлюють найбурхливіші зимові паводки - частка поверхневого стоку яких може досягати $80 \%$ і більше. Тобто лише $20 \%$ води, що утворюється під час танення, потрапляє у грунт і потім, повільно просочуючись у ньому, тече в русло, решта швидко стікає до русла по поверхні схилів, зумовлюючи різке підняття рівнів води у річці. Об'єм поверхневого стоку паводків зменшується зі зростанням лісистості водозборів. Зі зміною лісистості від $30 \%$ до
$93 \%$, частка поверхневого стоку зменшується у середньому у $1,2-1,5$ раза.

За дослідний період на всіх водозборах сніготанення починалось майже одночасно. У 1989, 1990, 1994 роках весна була досить ранньою, як наслідок - сніготанення на більшості водозборів почалось у ІІІ декаді лютого. В інші роки водопілля починалося у березні. Закінчення весняного водопілля переважно приурочено до квітнятравня. Хоч після теплих із частими потепліннями зим воно може закінчитися ще й у березні (1985, 1989 рр. на водозборах р. Славська - смт Славське; р. Лужанка с. Гошів; p. Рожанка - с. Рожанка; р. Дністер - с. Стрілки). Інколи на період сніготанення випадає велика кількість дощових опадів, і тоді затяжні водопілля переходять у дощові паводки, які можуть продовжуватися до I декади липня (1989 р. на водозборах р. Лужанка - с. Гошів; р. Рожанка - с. Рожанка).

Тривалість весняних водопіль на більшості малолісистих водозборів рідко перевищувала один місяць (табл. 3). I навпаки, на лісистих водозборах середня тривалість водопіль дорівнювала приблизно 2,5 місяці, що вказує на помірне танення снігу і рівномірну водовіддачу під час сніготанення на цих територіях. Найменш тривале весняне водопілля зафіксовано на водозборах р. Дністер - с. Стрілки i p. Славська смт Славське. В окремі роки воно продовжувалось всього 6 днів. Оскільки ці водозбори недостатньо заліснені, то це явище, можливо, зумовлене постійними потепліннями взимку, що сприяло таненню снігу під час потеплінь і зменшенню снігозапасів на початок весни.

Табл. 3. Тривалість весняного водопілля на водозборах, дні

\begin{tabular}{|c|c|c|c|c|c|c|c|c|c|c|c|c|c|c|c|c|c|}
\hline \multirow[b]{2}{*}{$\begin{array}{l}\text { № } \\
3 / \Pi\end{array}$} & \multirow[b]{2}{*}{ Назва річки } & \multicolumn{16}{|c|}{ Рік } \\
\hline & & ळ్ & $\stackrel{\mathscr{\infty}}{\varrho}$ & 市 & $\stackrel{2}{2}$ & $\stackrel{\circ}{\stackrel{一}{二}}$ & $\stackrel{\hat{\infty}}{\Omega}$ & $\begin{array}{l}\infty \\
\stackrel{\infty}{\varrho}\end{array}$ & $\stackrel{\infty}{\stackrel{\alpha}{二}}$ & ฉ & $\bar{\sigma}$ & ๙ & $\tilde{\sigma}$ & ஓे &  & 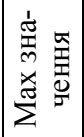 & 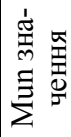 \\
\hline 1 & р. Яблунька - м. Турка & 52 & 46 & 25 & 42 & 17 & 36 & 44 & - & - & - & - & - & - & 37 & 52 & 17 \\
\hline 2 & $\begin{array}{l}\text { p. Славська - смт } \\
\text { Славське }\end{array}$ & 88 & 6 & 23 & 10 & 7 & 14 & 10 & 9 & 16 & 13 & 18 & 12 & 7 & 11 & 88 & 6 \\
\hline 3 & р. Дністер - с. Стрілки & 14 & 10 & 22 & 10 & 69 & 11 & 6 & 12 & 14 & 21 & 27 & 16 & 25 & 19 & 69 & 6 \\
\hline 4 & р. Рибник - с. Майдан & 94 & 73 & 30 & 79 & 76 & 87 & 65 & 64 & 98 & 109 & 81 & 67 & 88 & 79 & 98 & 30 \\
\hline 5 & p. Опір - м. Сколе & 47 & 47 & 21 & 37 & 23 & 35 & 49 & 97 & 92 & 24 & 54 & 47 & 61 & 43 & 97 & 21 \\
\hline 6 & р. Орява - х. Святослав & 79 & 73 & 37 & 93 & 69 & 87 & 64 & 60 & 89 & 24 & 98 & 57 & 93 & 71 & 98 & 24 \\
\hline 7 & р. Стрий - с. Матків & 80 & 69 & 41 & 94 & 62 & 40 & 65 & 94 & 118 & 70 & 66 & 63 & 80 & 72 & 118 & 40 \\
\hline 8 & р. Головчанка - с. Тухля & 85 & 69 & 33 & 72 & 71 & 48 & 62 & 59 & 89 & 70 & 84 & 57 & 82 & 70 & 89 & 33 \\
\hline 9 & р. Сукіль - с. Тисів & 71 & 80 & 35 & 57 & 71 & 61 & 66 & 72 & 90 & 58 & 83 & 61 & 83 & 68 & 90 & 35 \\
\hline 10 & р. Лужанка - с. Гошів & 65 & 76 & 30 & 73 & 72 & 114 & 48 & 12 & 57 & 34 & 120 & 60 & 54 & 62 & 120 & 12 \\
\hline 11 & р. Рожанка - с. Рожанка & 80 & 72 & 33 & 42 & 64 & 104 & 62 & - & - & - & - & - & - & 65 & 104 & 33 \\
\hline
\end{tabular}

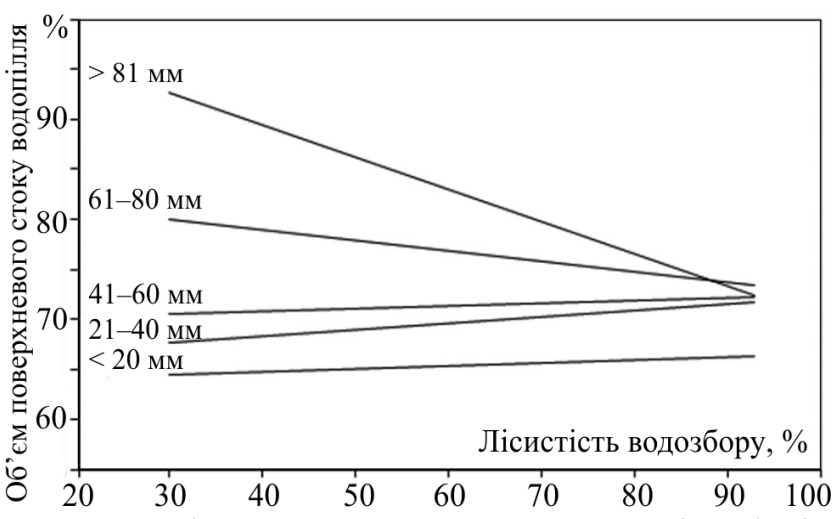

Рис. 3. Залежність об'єму поверхневого стоку водопілля від лісистості водозборів за різних запасів води в снігу
Найбільшу тривалість весняних водопіль простежуємо на водозборі р. Стрий - с. Матків, саме тут формується потужний сніговий покрив (див. табл. 2). Тривалий період водопіль на водозборах р. Лужанка c. Гошів, p. Рожанка - с. Рожанка очевидно зумовлений низькими температурами повітряних мас під час сніготанення.

Аналіз розрахованого об'єму поверхневого стоку кожного водопілля показав, що його частка в загальному стоці водопілля може змінюватися у широких межах від 20 \% до 93 \%. Характер залежності об'єму поверхневого стоку водопілля від лісистості (рис. 3) вказує, що за різних запасів води в снігу на початок водопілля вплив лісу на нього різний. Максимальний вияв стокорегулювальних можливостей лісу простежуємо за сні- 
гозапасів, більших ніж 61 мм. Зі збільшенням лісистості водозбору від 30 до 93 \% частка поверхневого стоку водопілля зменшується у 1,1 раза за запасів 61-80 мм і в 1,3 раза за запасів понад 81 мм. Коли ж на водозборі запаси води не перевищують 60 мм, вплив лісу не простежують.

Висновки. Порівняно 3 метеорологічними умовами і рельєфом місцевості, лісистість має менший вплив на формування снігового покриву, проте встановлено, що максимальні товщини снігового покриву простежують за лісистості водозбору в діапазоні 40-60 \%.

Максимальний прояв стокорегулювальних можливостей лісу під час формування зимових паводків спостерігають за снігозапасів понад 41 мм і проявляється у збільшенні тривалості паводків на 5-17 днів.

Максимальний прояв стокорегулювальних можливостей лісу під час весняних водопіль спостерігають за снігозапасів понад 61 мм і проявляється у зменшенні об'єму поверхневого стоку водопілля у 1,1-1,3 раза.

\section{Перелік використаних джерел}

Chubatyi, O. V. (1968). Zakhysna rol karpatskykh lisiv. Uzhhorod: Karpaty. 137 p. [In Ukrainian].

Dubakh, A. D. (1951). Les - kak hydrolohycheskyi faktor. MoscowLeningrad: Hoslesbumyzdat. 375 p. [In Russian].

Kulchitckii-Zhigailo, I. Ye. (2008). Lis i poveni: chi vse tak prosto? Dzerkalo tizhnia, 32. [In Ukrainian].

Kulchitckii-Zhigailo, I. Ye., \& Oshurkevich, O. Ye. (2007). Vpliv lisu na formuvannia zimovikh pavodkiv u Beskidakh. Scientific Bulletin of UNFU, 17(1), 23-28. [In Ukrainian].

Molchanov, A. A. (1970). Gidrologicheskaia rol lesa v razlichnykh prirodnykh zonakh SSSR. Gidrologicheskie issledovaniia v lesu. Moscow: Nauka. 359 p. [In Russian].

Subbotin, A. I. (1986). Stok talykh i dozhdevykh vod. (Po eksperimentalnym dannym). Moscow: Gidrometeoizdat. 319 p. [In Russian].

О. Е. Ошуркевич-Панкивская, Ю. И. Панкивский

Национальный лесотехнический университет Украины, г. Львов, Украина

\section{ВЛИЯНИЕ ЛЕСА НА НАКОПЛЕНИЕ И ТАЯНИЕ СНЕГОВ В ГОРАХ}

На основе данных о расходах воды, толщине снежного покрова и запасах воды в снеге за период с 1981 по 1994 гг. для одиннадцати водосборов рек северного мегасклона Украинских Карпат (бассейн реки Днестр) построены совмещенные гидрографы стока воды и запасов воды в снеге. На полученных графиках выделены зимние паводки и весенние половодья, для каждого из которых определены: продолжительность, запас воды в снеге к началу снеготаяния, объем поверхностного и грунтового стока. На основе результатов расчетов и морфометрических характеристик водосборов, а именно уклона склонов, высоты над уровнем моря, лесистости, проанализировано влияние лесных насаждений на накопление снега, продолжительность и объемы поверхностного стока зимних паводков и весенних половодий. Установлено, что по сравнению с метеорологическими условиями и рельефом местности лесистость имеет меньшее влияние на формирование снежного покрова, однако максимальные толщины снежного покрова наблюдаются при лесистости водосбора в диапазоне 40-60 \%; максимальное проявление стокорегулирующих возможностей леса при формировании зимних паводков наблюдается при снегозапасах более 41 мм и проявляется в увеличении продолжительности паводков на 5-17 дней; максимальное проявление стокорегулирующих возможностей леса во время весенних половодий наблюдается при снегозапасах более 61 мм и проявляется в уменьшении объема поверхностного стока половодья в 1,1-1,3 раза.

Ключевые слова: весенние половодья; зимние паводки; запасы воды в снеге; объем поверхностного стока паводка; объем поверхностного стока половодья; продолжительность паводка; продолжительность половодья.

O. Ye. Oshurkevych-Pankivska, Yu. I. Pankivskyi

Ukrainian National Forestry University, Lviv, Ukraine

\section{INFLUENCE OF FOREST ON SNOW ACCUMULATION AND MELTING IN THE MOUNTAINS}

Forest plantations during winter and spring snow melting are known to significantly reduce the input of the surface component in the total runoff volume from catchments. The combination on a river catchment of forested and non-forested areas creates favourable conditions for the formation of snow cover and causes the longest period of snow melting and the lowest peaks of winter floods and spring freshets, i.e. auspicious conditions for the formation of snowmelt runoff. However, despite more than centuries-old history of forestry and hydrological research, the issue of runoff regulatory influence of forest, especially in mountainous conditions, remains controversial. On the basis of data on water flow, thickness of the snow cover and reserves of water in snow under period from 1981 to 1994 for 11 watersheds of the Northern mega hillside of the Ukrainian Carpathians (the Dniester River basin) the combined hydrographs of water runoff and water reserves in snow were built. On the obtained graphs winter floods and spring freshets are allocated. The duration, the reserve of water in the snow at the beginning of snowmaking, the volumes of surface and ground runoff are determined for each of them. On the basis of the results of calculations and morphometric characteristics of water catchments the influence of the forest plantations on the accumulation of snow, duration and volumes of surface runoff of winter floods and spring freshets is analysed. It has been established that in comparison with meteorological conditions and terrain topography, forest has a lesser effect on the formation of snow cover. However, the maximum thickness of snow cover is observed at the catchment forests within the range of 40-60\%; the maximum manifestation of the runoff regulatory capabilities of forest during the formation of winter floods is observed at snow reserves greater than $41 \mathrm{~mm}$ and reflected in floods duration increasing for 5-17 days; the maximum manifestation of the runoff regulatory capabilities of forest during spring freshets is observed at snow reserves over $61 \mathrm{~mm}$.

Keywords: spring freshet; winter floods; reserves of water in the snow; surface runoff volume of the flood; surface runoff volume of the freshet; flood duration; freshet duration. 